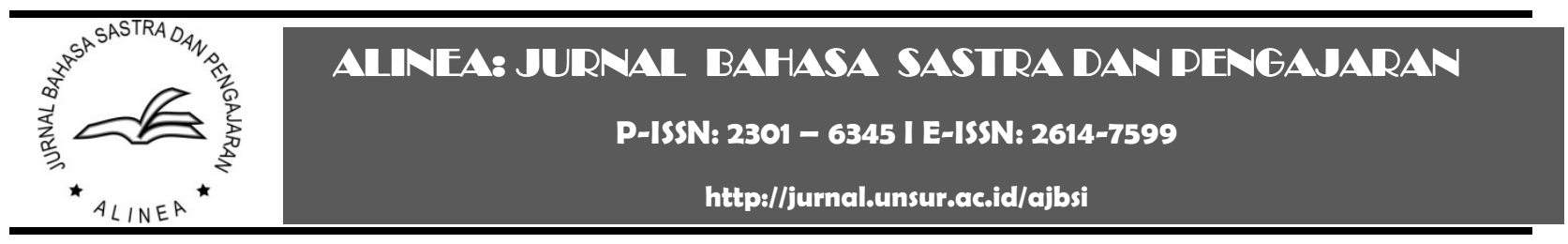

\title{
PRINSIP KERJA SAMA GRICE DALAM NOVEL RAUMANEN KARYA MARIANNE KATOPPO
}

\author{
Maya Novalia Pulungan \\ UIN Syarif Hidayatullah Jakarta, Indonesia
}

Riwayat artikel:

Dikirim: 9 Juli 2020

Direvisi: 5 Maret 2021

Diterima: 8 Maret 2021

Diterbitkan: 27 April 2021

Katakunci:

kerja sama, maksim, novel, pematuhan, pelanggaran

Keywords:

cooperation, maxim, novel, compliance, violation

Alamat surat

mayanovalia19@gmail.com

\begin{abstract}
Abstrak:
Artikel ini akan mendeskripsikan prinsip kerja sama yang dicetuskan oleh Grice dalam novel "Raumanen" karya Marianne Katoppo serta pelanggaran prinsip kerja sama yang dilakukan oleh tokoh-tokoh dalam novel. Metode yang digunakan dalam penelitian adalah metode kualitatif. Hasil penelitian menunjukkan bahwa terdapat pematuhan dan pelanggaran prinsip kerja sama Grice yang dilakukan oleh tokoh-tokoh dalam novel. Pematuhan terhadap prinsip kerja sama menandakan bahwa para tokoh memahami konteks pertuturan sehingga mereka memberikan kontribusi yang baik pada saat proses komunikasi berlangsung. Sementara itu, pelanggaran prinsip kerja sama merupakan hal yang paling banyak dilakukan oleh para tokoh. Hal ini disebabkan ada maksud dan tujuan yang ingin dicapai. Peneliti menemukan maksud-maksud pelanggaran tersebut, yaitu ingin memberi peringatan, meminta penjelasan, menciptakan humor, memberi penjelasan, sopan santun, menyembunyikan suatu hal, mengungkapkan suatu hal, dan mencari-cari alasan.
\end{abstract}

\begin{abstract}
:
This study aims to describe the cooperative principles by Grice in novel Raumanen by Marianne Katoppo and violations of the cooperative principle performed by the characters in the novel. The research method used qualitative. The results of the study showed that there were implementation and violations of the Grice cooperative principle performed by the characters in the novel. Following cooperative principle indicated that the characters understood the context of utterance so they gave appropriate contribution during the communication. Meanwhile, the violation of cooperative principles was the most commonly performed by the characters. This was because there were intention and objective to achieve. The researcher found the intentions of the violation to give a warning, ask for explanation, create humor, give explanation, politeness, hide something, express something, and look for reasons.
\end{abstract}

\section{PENDAHULUAN}

Sebagai makhluk sosial, manusia memiliki kemampuan untuk berinteraksi dengan orang lain. Proses interaksi tersebut dikemas dalam bentuk percakapan, dengan bahasa sebagai medianya. Dalam hal ini, bahasa menjadi sangat penting bagi kehidupan manusia. Bahasa yang digunakan tentunya harus dipahami oleh masing-masing individu agar proses komunikasi dapat berjalan dengan lancar, karena sejatinya setiap individu mempunyai maksud dan tujuan yang ingin dicapai ketika berkomunikasi dengan orang lain. Proses komunikasi yang efektif dan interaktif pada dasarnya melibatkan dua pihak yaitu penutur dan lawan tutur sedangkan lawan tutur menerima informasi tersebut. Oleh karena itu, apa yang ada dalam pikiran penutur tersampaikan, dan 
komunikasi dapat dikatakan berhasil. Proses perubahan pembicaraan terjadi begitu cepat, terasa sebagai suatu peristiwa biasa dan wajar (Yuliana et al., 2013). Dengan demikian, kegiatan komunikasi akan berhasil ketika setiap individu memberikan sumbangan atau kerja sama yang baik dalam pertuturan.

Pertuturan atau tindak tutur merupakan objek kajian pragmatik, yaitu studi bahasa yang mempelajari relasi bahasa dengan konteksnya (Rahardi, 2005). Pragmatik mengkaji maksud penutur dalam menuturkan satuan lingual tertentu pada sebuah bahasa karena yang dikaji dalam pragmatik adalah makna. Sebuah tuturan yang dikeluarkan oleh seseorang tentu tidak lepas dari konteks yang melatarbelakangi terjadinya pertuturan tersebut. Ketika peserta tutur terlibat dalam pertuturan, konteks menjadi sangat penting untuk menciptakan komunikasi yang efektif. Pemahaman terhadap konteks oleh penutur dan kawan tutur dapat membantu tercapainya tujuan komunikasi. Oleh karena itu, dalam sebuah pertuturan, ada aturan-aturan yang harus dipatuhi oleh peserta tutur.

Prinsip kerja sama pertama kali dicetuskan oleh Grice. Menurutnya, prinsip kerja sama dalam kegiatan komunikasi menghendaki peserta tutur untuk memberikan kontribusi yang baik. Prinsip kerja sama didasari oleh asumsi bahwa dalam berkomunikasi, penutur dan kawan tutur bersedia bekerja sama (Yuniseffendri, 2011). Prinsip ini menuntut peserta tutur agar apa yang dikatakannya cukup relevan, jelas, dan mudah dipahami dengan situasi yang ada dalam percakapan itu. Dengan demikian, dapat dikatakan bahwa ada kaidah-kaidah yang harus ditaati oleh peserta tutur agar percakapan berjalan dengan lancar. Pada banyak kesempatan, asumsi kerja sama dapat dinyatakan sebagai suatu prinsip kerja sama dalam percakapan dan dapat dirinci ke dalam empat sub-prinsip, yang disebut maksim. Maksim adalah prinsip yang harus ditaati oleh peserta pertuturan dalam berinteraksi, baik secara tekstual maupun interpersonal dalam upaya melancarkan jalannya proses komunikasi (Kushartanti, 2009).

Lebih lanjut Grice menjelaskan, ketika peserta tutur melakukan kegiatan komunikasi harus mematuhi empat maksim (Leech, 1993). Maksim merupakan prinsip yang harus ditaati oleh peserta pertuturan dalam berinteraksi, baik secara tekstual maupun interpersonal dalam upaya melancarkan jalannya proses komunikasi. Keempat maksim itu adalah maksim kuantitas (maxim of quantity); maksim kualitas (maxim of quality); maksim relevansi (maxim of relevance); dan maksim cara (maxim of manner) (BAM et al., 2018). Peserta dalam pertuturan harus terlibat aktif agar kegiatan tersebut dapat berjalan dengan lancar. Sebaliknya, jika salah satu peserta tutur tidak memberikan kontribusi yang baik, dapat dipastikan proses bertutur tidak akan berjalan dengan lancar. Hal ini akan berdampak pada maksud dan tujuan yang hendak dicapai oleh peserta tutur dalam kegiatan tersebut. Namun, seringkali prinsip kerja sama itu dilanggar oleh peserta tutur. Pelanggaran terhadap maksim percakapan akan menimbulkan kesan janggal dan tidak alamiah. Hal ini tampak apabila informasi yang diberikan terasa berlebihan (pelanggaran maksim kuantitas), tidak benar (pelanggaran maksim kualitas), tidak relevan (pelanggaran maksim relevansi), dan lain-lain (Shinta, 2010). Pelanggaran yang dilakukan bukan semata-mata peserta tutur tidak saling memahami konteks pertuturan, tetapi ada maksud dan tujuan yang ingin dicapai, seperti ingin memberikan penjelasan dan pemahaman yang lebih dari apa yang ia katakan, ingin menciptakan humor, ingin menyindir, atau sekadar mencari-cari alasan.

Tidak hanya dalam komunikasi dan proses interaksi sosial, bahasa ternyata memiliki peranan penting dalam komunikasi sastra. Novel bukan hanya berkaitan dengan sastra, namun novel juga berkaitan dengan bahasa. Coba kita perhatikan beberapa produk sastra seperti puisi, cerpen, atau bahkan novel. Tentu kita semua setuju bahwa bahasa mempengaruhi nilai dari karya sastra tersebut. Terutama pada novel, bisa kita lihat penggunaan bahasanya pada dialog antar 
tokoh. Novel merupakan salah satu karya fiksi yang ditulis dalam bentuk cerita. Pada hakikatnya novel mendayagunakan bahasa untuk mengungkapkan tentang kehidupan manusia. Kalimat yang dituturkan oleh tokohtokoh dalam yang digambarkan pengarang dalam sebuah novel diharapkan dapat dipahami dengan baik oleh pembaca (Beden \& Zahid, 2015).

Novel menarik untuk dianalisis karena novel sejatinya tidak akan terlepas dari bahasa sebagai alat komunikasi di dalamnya (Maemunah, 2019). Novel sebagai media berbentuk tulisan adalah karangan prosa panjang yang mengandung rangkaian cerita kehidupan seseorang. Rangkaian cerita tersebut menghadirkan beberapa tokoh yang berinteraksi untuk menciptakan suasana tertentu kepada pembaca. Tentunya interaksi antara satu tokoh dengan tokoh lain itu dikemas dalam bentuk percakapan/dialog. Dialog antartokoh dalam sebuah novel kadangkala terlihat memenuhi prinsip kerja sama dalam pertuturan, namun tidak menutup kemungkinan akan melanggar prinsip kerja sama tersebut (Lestari et al., 2019).

Di dalam novel kita juga dapat memperoleh wawasan dengan bahasa tulis yang disampaikan oleh pengarang kepada pembaca. Bahasa yang digunakan oleh setiap pengarang akan memberikan daya imajinasi yang kuat kepada si pembaca dan novel juga merupakan suatu karya sastra yang hasilnya akan terus dinikmati oleh setiap pembaca. Novel juga merupakan cerita mengenai kehidupan manusia yang didalamnya terdapat konflik yang terjadi antar tokoh. Berbagai peristiwa dijelaskan pada setiap percakapanpercakapan yang dilakukan pada masingmasing tokoh (Veronika et al., 2017). Oleh karena itu, novel Raumanen menjadi pilihan yang tepat untuk dijadikan bahan penelitian tentang prinsip kerja sama yang dicetuskan oleh Grice, melihat dalam novel ini banyak dialog yang terjadi antartokoh. Untuk menjawab persoalan tersebut, ada beberapa pertanyaan yang diajukan, yaitu: Pertama, bagaimana bentuk pematuhan prinsip kerja sama yang dilakukan oleh para tokoh dalam novel Raumanen? Kedua, bagaimana bentuk pelanggaran prinsip kerja sama yang dilakukan oleh para tokoh dalam novel Raumanen? Ketiga, apa maksud dan tujuan yang ingin dicapai para tokoh ketika melakukan pelanggaran terhadap prinsip kerja sama?

Penelitian tentang prinsip kerja sama pernah dilakukan oleh Tiara (2017) berjudul "Pelanggaran Prinsip Kerjasama dalam Anime Gintama Episode 3-Episode 5" (Tiara, 2017). Peneliti menemukan pelanggaran-pelanggaran maksim yang dilakukan oleh tokoh dalam cerita. Pelanggaran terhadap maksim kualitas lebih sering terjadi karena beberapa sebab yang mengharuskan penutur berbohong . Penelitian dengan kajian serupa juga pernah dilakukan oleh Lyra, dkk. (2020) berjudul "Analisis Kepatuhan Terhadap Prinsip Kerja Sama Grice Dalam Komik Sunda Si Mamih" (An Analysis Of Grice's Cooperative Principle In Sundanese's Comic “Si Mamih" (Lyra et al., 2020). Peneliti menemukan banyak humor yang dibentuk dari pelanggaran prinsip kerja sama, khususnya yang dilakukan oleh tokoh utama.

Berdasarkan tinjauan di atas, persamaan penelitian terletak pada teori yang digunakan, yaitu prinsip kerja sama. Sementara itu, perbedaan penelitian di atas dengan penelitian ini adalah sumber data dan masalah yang dikaji. Jika penelitian di atas membatasi kajian pada pelanggaran maksim, dalam penelitian ini mencakup pelanggaran dan pematuhan maksim yang dilakukan oleh para tokoh dalam novel. Hasil penelitian menunjukkan bahwa terdapat pematuhan dan pelanggaran prinsip kerja sama Grice yang dilakukan oleh tokohtokoh dalam novel. Pematuhan terhadap prinsip kerja sama menandakan bahwa para tokoh memahami konteks pertuturan, sehingga mereka memberikan kontribusi yang baik pada saat proses komunikasi berlangsung. Sementara itu, pelanggaran prinsip kerja sama merupakan hal yang paling banyak dilakukan oleh para tokoh. Hal ini disebabkan ada maksud dan tujuan yang ingin dicapai. Peneliti menemukan maksud-maksud pelanggaran tersebut, yaitu ingin memberi peringatan, 
meminta penjelasan, menciptakan humor, memberi penjelasan, sopan santun, menyembunyikan suatu hal, mengungkapkan suatu hal, dan mencari-cari alasan.

\section{METODE}

Metode penelitian yang digunakan, yaitu penelitian kualitatif. Penelitian kualitatif adalah penelitian yang bermaksud untuk memahami fenomena tentang apa yang dialami oleh subjek penelitian, misalnya perilaku, persepsi, motivasi, tindakan, dan lain-lain secara holistik, dan dengan cara deskripsi dalam bentuk kata-kata dan bahasa pada suatu konteks khusus yang alamiah dan dengan memanfaatkan berbagai metode alamiah. Penelitian ini akan mendeskripsikan prinsip kerja sama yang terdapat dalam dialog antartokoh pada novel Raumanen karya Marianne Katoppo.

Sumber data primer yang digunakan dalam penelitian ini adalah novel Raumanen karya Marianne Katoppo. Berikut adalah identitas novel tersebut:

$\begin{array}{ll}\text { Judul buku } & \text { : Raumanen } \\ \text { Pengarang } & \text { : Marianne Katoppo }\end{array}$

Penerbit : Metafor Publishing

Tebal : ix +134 halaman

Selain itu, sumber data sekunder yang digunakan dalam penelitian adalah buku-buku Pragmatik yang berkaitan dengan prinsip kerja sama. Peneliti juga menggunakan sumbersumber lain yang relevan guna menambah pengetahuan tentang prinsip kerja sama Grice.

Penelitian ini dilakukan dengan teknik membaca dan menyimak seluruh novel. Teknik membaca dan menyimak diperlukan untuk menemukan data-data berupa dialog antartokoh dalam novel yang sesuai dengan prinsip kerja sama Grice. Selanjutnya datadata yang diperoleh akan dicatat pada lembar kertas yang sudat disediakan. Setelah dicatat, data-data tersebut diklasifikasikan sesuai dengan bagian-bagian yang ada dalam prinsip kerja sama Grice.

\section{HASIL PENELITIAN}

Data yang digunakan pada penelitian ini terdapat dalam novel Raumanen karya Marianne Katoppo, salah satu novel sastra modern yang ada di Indonesia. Novel ini terdiri atas 18 sub-bab. Dari 18 sub-bab tersebut, 8 sub-bab memakai sudut pandang "Aku" dengan pembagian 5 sub-bab berisi kisah tentang tokoh Raumanen dan 3 sub-bab berisi kisah tentang tokoh Monang. Selain itu, 10 sub-bab bercerita dengan menggunakan sudut pandang orang ketiga, yaitu "Dia". Pada sub-bab yang menggunakan sudut padat orang pertama "Aku", cerita disuguhkan dengan menggunakan monolog dari tokoh. Peristiwaperistiwa yang terjadi diungkapkan melalui pemikiran dan batin para tokoh, sehingga tidak terjadi komunikasi dua arah. Berbeda dengan sub-bab yang menggunakan sudut pandang orang ketiga "Dia", peristiwa-peristiwa yang disuguhkan tergambar melalui dialog atau percakapan yang dilakukan antartokoh, sehingga komunikasi dua arah pun terjalin. Maka dari itu, peneliti mengambil percakapan antartokoh yang terjadi dalam 10 sub-bab tersebut.

Hasil pada penelitian ini menemukan bahwa tokoh-tokoh dalam novel Raumanen melakukan pematuhan dan pelanggaran terhadap prinsip kerja sama. Dari 20 percakapan yang telah dianalisis, terdapat 5 percakapan mematuhi semua maksim, yaitu maksim kuantitas, maksim kualitas, maksim cara, dan maksim relevan. Selain itu, terdapat 2 percakapan mematuhi dua maksim, yaitu maksim relevan dan maksim cara, serta 13 percakapan melakukan pelanggaran terhadap tiga maksim, yaitu maksim kuantitas, maksim kualitas, dan maksim cara. Pematuhan yang sering dilakukan terjadi pada maksim relevan, yaitu sebanyak 19 percakapan, sedangkan pelanggaran sering terjadi pada maksim kuantitas dan maksim cara, yaitu masingmasing sebanyak 15 percakapan. Setelah dianalisis, peneliti menemukan bahwa pematuhan yang dilakukan oleh para tokoh 
tidak lepas dari pemahaman mereka terhadap konteks pertuturan. Baik penutur maupun kawan tutur mencoba memahami konteks pertuturan sehingga mereka dapat memberikan kontribusi yang baik pada saat terjadinya komunikasi. Pelanggaran terhadap prinsip kerja sama merupakan hal yang banyak terjadi di dalam novel. Jenis pelanggaran yang dilakukan pun mermacam-macam, baik dari segi faktualnya informasi yang diberikan, kebutuhan informasi yang diinginkan oleh penutur, maupun dari segi kejelasan informasi yang diberikan. Akan tetapi, bukan berarti pelanggaran terhadap prinsip kerja sama yang dilakukan oleh para tokoh disebabkan oleh ketidakpahaman mereka terhadap konteks pertuturan. Setelah ditelisik, ternyata ada maksud dan tujuan dari kawan tutur melakukan pelanggaran tersebut, seperti ingin memberi peringatan, meminta penjelasan, menciptakan humor, memberi penjelasan, sopan santun, menyembunyikan suatu hal, mengungkapkan suatu hal, dan mencari-cari alasan. Secara berturut-turut akan dibahasa maksud dan tujuan kawan tutur melakukan pelanggaran terhadap prinsip kerja sama sebagai berikut:

\section{a) Memberi Peringatan}

Pelanggaran prinsip kerja sama yang dilakukan oleh para tokoh dalam novel salah satunya memiliki maksud dan tujuan untuk memberi peringatan. Hal ini tidak lepas dari rasa kesal dari kawan tutur terhadap perilaku penutur, sebagaimana terlihat dalam kutipan novel berikut:

Penutur: "Rik! Monang mendelik. "Mengapa kau begitu ganas menyerangku? Mencemoohkan diriku yang tak bersalah?" Tetapi ia tampaknya sama sekali tak tersinggung.

Kawan tutur: "Bung," kata Patrik sungguhsungguh. "Kalau kau mau mengganyang, menelan mentah-mentah cewek-cewek cakep di sini, kupersilakan. Tetapi anak kecil itu ..."

Konteks tuturan di atas terjadi ketika penutur berkenalan dengan teman perempuan yang dibawa oleh kawan tutur ke acara perkumpulan gerakan mahasiswa. Namun, kawan tutur tidak menyukai hal tersebut sebab penutur dikenal sebagai laki-laki playboy sehingga ia memberi ujaran yang seolah-olah mencemooh penutur. Dari tuturan di atas tampak bahwa jawaban yang diberikan kawan tutur tidak sesuai dengan harapan yang dibutuhkan oleh penutur. Dengan kata lain, kawan tutur tidak memberikan jawaban seinformatif mungkin. Selain itu, jawaban dari kawan tutur yang menyiratkan makna bahwa penutur ingin mendekati semua perempuan cantik yang datang pada acara tersebut tidak sepenuhnya dapat dipertanggungjawabkan karena tidak disertai bukti yang kuat dan tidak jelas. Dalam hal ini, kawan tutur telah melakukan pelanggaran terhadap maksim kuantitas, maksim kualitas, dan maksim cara. Dalam maksim kuantitas ini, seorang penutur diharapkan dapat memberikan informasi yang cukup, relatif memadai, dan seinformatif mungkin. Memberikan informasi yang terlalu berlebihan dan tidak jelas merupakan suatu pelanggaran (Savitri et al., 2015). Seorang penutur dikatakan melanggar maksim kualitas apabila penutur mengatakan sesuatu yang sebenarnya tidak sesuai dengan yang harus dilakukan oleh seseorang atau mengatakan sesuatu tidak sesuai dengan fakta yang terjadi pada saat terjadi tuturan (Fauziah et al., 2018). Namun, pelanggaran tersebut memiliki maksud untuk memberi peringatan terhadap penutur agar tidak mendekati perempuan bernana Raumanen yang ia bawa ke acara perkumpulan tersebut.

\section{b) Meminta Penjelasan}

Tanpa disadari, terkadang pelanggaran terhadap prinsip kerja sama dilakukan oleh kawan tutur bertujuan untuk meminta penjelasan dari penutur. Ujaran dari kawan tutur keluar secara spontan sebab ia tidak memahami maksud dari penutur. Sebagaimana terlihat dalam kutipan novel berikut:

Penutur: "He, Keke, sejak kapan kau berpacaran dengan buaya darat itu?"

Kawan tutur: "Apa?" tanya Manen tercengang. 
Konteks tuturan di atas terjadi ketika penutur mendengar kabar tentang kedekatan kawan tutur dengan Monang. Penutur menyebut buaya darat sebab Monang terkenal sebagai laki-laki yang memiliki banyak pacar, dan penutur merupakan salah satu perempuan yang pernah ia dekati. Jika dilihat, pertuturan di atas tidak memiliki keterkaitan satu sama lain. Jawaban yang diberikan kawan tutur tidak memberikan informasi, bukti yang memadai, serta menimbulkan kebingungan. Dalam hal ini, kawan tutur telah melakukan pelanggaran terhadap maksim kuantitas, maksim kualitas, dan maksim cara. Namun, jika dicermati antara pertanyaan dengan jawaban masih memiliki hubungan. Kawan tutur memahami konteks buaya darat yang dimaksud penutur adalah Monang. Pelanggaran yang dilakukan oleh kawan tutur memiliki tujuan untuk meminta penjelasan dari pertanyaan yang diajukan oleh penutur tekait kedekatannya dengan Monang. Pertanyaan kawan tutur yang memperlihatkan rasa heran itu menyiratkan makna bahwa dari mana penutur memperoleh kabar itu.

\section{c) Menciptakan Humor}

Pelanggaran prinsip kerja sama yang dilakukan oleh para tokoh dalam novel juga bermaksud untuk menciptakan humor ketika pertuturan berlangsung. Pelanggaran ini dilakukan bukan disebabkan ketidakpahaman kawan tutur terhadap konteks pertuturan. Sebaliknya, kawan tutur memahi konteks percakapan sehingga ia sengaja melakukan pelanggaran tersebut. Hal itu terlihat dalam kutipan novel berikut:

Penutur: "Umur berapa kau mulai sekolah? Sudah bisa jalan?

Kawan tutur: "Sudah," kata Manen, "tetapi masih suka ngompol!"

Konteks pertuturan di atas terjadi ketika penutur ingin melakukan pendekatan dengan cara menyakan masa kecil dari kawan tutur. Dari pertuturan di atas, terlihat bahwa kawan tutur melanggar prinsip kerja sama sebab ia hanya menjawab satu dari dua pertanyaan yang diajukan oleh penutur. Dalam hal ini, kawan tutur memberikan jawaban yang tidak informatif, tidak memberikan bukti yang memadai, serta tidak jelas sebab kawan tutur tidak menjawab umur berapa ia masuk sekolah. Kawan tutur justru memberikan informasi yang tidak sesuai dengan pertanyaan penutur dengan menjawab "tetapi masih suka ngompol". Maka dapat disimpulkan bahwa kawan tutur telah melakukan pelanggaran prinsip kerja sama. Namun perlu digaris bawahi bahwa pelanggaran tersebut dilakukan kawan tutur dengan maksud ingin menciptakan kesan humor kepada penutur. Hal ini juga sebagai proses pendekatan antara penutur dan kawan tutur.

\section{d) Memberi Penjelasan}

Dalam sebuah pertuturan, seringkali kawan tutur memberikan informasi melebihi yang dibutuhkan oleh penutur. Hal ini menyebabkan terjadinya pelanggaran terhadap prinsip kerja sama, khususnya maksim kuantitas. Namun, informasi yang diberikan melebihi apa yang dibutuhkan itu tidak lepas dari keinginan kawan tutur untuk memberikan penjelasan dan pemahaman kepada penutur, sehingga tidak terjadi kesalahpahaman antara satu sama lain. Sebagaimana terlihat dalam kutipan berikut:

Penutur: "Apakah Loce juga salah seorang calon dari ibumu?" tanya Manen.

Kawan tutur: Monang tertawa, tetapi nadanya tidak gembira. "Ah, Raumanen! Kau begitu bodoh ... Calon-calon yang disodorkan oleh ibuku selalu gadis-gadis Batak yang paling cocok menurut hukum adat ..." Dilepaskannya tangan Manen, lalu ia menyalakan rokok. "Mengenai Loce itu ... ya, patut kuberitahukan kepadamu. Kami teman lama karena ia seangkatan denganku ketika masuk gerakan mahasiswa dulu. Lalu dia sering ke Bandung, menginap di rumah Hilda itu. Dan karena mobilku dulu memang menjadi semacam bis umum, aku sering mengantarkannya. Suatu malam, entah sebab apa, aku mengantarnya paling terakhir ... dan di muka rumahnya, aku terlanjur menciumnya ..." 
Konteks pertuturan di atas membicarakan hubungan percintaan masa lalu yang pernah dialami oleh kawan tutur dengan perempuan bernama Loce. Jika dilihat secara sepintas, jawaban yang diberikan kawan tutur tidak sesuai dengan pertanyaan penutur, sebab pertanyaan yang diajukan oleh penutur menghendaki jawaban "ya" atau "tidak". Kawan tutur memberikan informasi melebihi apa yang dibutuhkan oleh penutur dan jawaban tersebut diungkapkan secara berkepanjangan, sehingga menimbulkan kebingungan bagi penutur. Dalam hal ini kawan tutur telah melanggar prinsip kerja sama berupa maksim kualitas dan maksim cara. Maksim cara mengharuskan bahwa setiap peserta percakapan dapat memberikan informasi secara langsung, tidak taksa, dan runtut. Apabila hal ini dilanggar tentunya orang tersebut mempunyai tujuan tertentu (Panduwinata, n.d.). Namun, pertuturan di atas memiliki keterkaitan satu sama lain. Jawaban yang diberikan oleh kawan tutur menyiratkan makna bahwa Loce bukan calon yang diberikan ibunya, sebab ia tidak memenuhi kriteria yang sesuai dengan adat Batak. Tampaknya kawan tutur sengaja melanggar prinsip kerja sama karena ingin memberikan penjelasan dan pemahaman kepada kawan tutur tentang masa lalunya. Menurut kawan tutur, hal tersebut perlu dilakukan karena ia sedang dalam proses pendekatan dengan penutur, sehingga tidak ada kesalahpahaman antara satu sama lain.

\section{e) Sopan Santun}

Dalam novel Raumanen, pelanggaran terhadap prinsip kerja sama dilakukan dengan maksud ingin memperlihatkan sikap sopan santun kepada penutur. Sikap ini sebagai balasan terhadap sikap sopan santun yang ditunjukkan terlebih dahulu oleh penutur.

Penutur: "Zus toh tidak keberatan saya diantar pulang dulu?"

Kawan tutur: Manen terpaksa mengakui dalam hatinya bahwa kesopanan gadis ini betul-betul mendarah daging padanya. Sekalipun kecewa, ia masih tahu diri. Masih minta maaf, minta izin. Tidak menyepak, menerjang .... Tetapi Manen cuma menjawab semua kesopanan itu dengan kekasaran terpendam, "Ah, Monang toh bukan supir pribadiku ... Zus."

Konteks pertuturan di atas terjadi ketika penutur meminta izin kepada kawan tutur untuk diantar pulang terlebih dahulu oleh kekasihnya. Penutur merupakan salah satu perempuan yang memendam rasa suka terhadap Monang. Meskipun kecewa sebab Monang sudah menjalin kasih dengan kawan tutur, penutur tetap menghargai dan memiliki sikap sopan santun kepada kawan tutur. Dari pertuturan di atas, jawaban kawan tutur tidak memenuhi kebutuhan yang diinginkan oleh penutur, sebab pertanyaan penutur menghendaki jawaban "ya" atau "tidak". Tetapi kawan tutur memberikan jawaban yang butuh interpretasi, sehingga menyebabkan makna ambigu bagi penutur. Namun jika dicermati, jawaban kawan tutur menyiratkan makna bahwa walaupun kekasihnya, tetapi ia tidak mempunyai hak penuh atas diri Monang. Monang boleh mengantar siapa saja termasuk penutur. Pelanggaran yang dilakukan oleh kawan tutur merupakan balasan sopan santun terhadap sikap hormat yang diberikan oleh penutur. Walaupun ia kesal, namun rasa itu hanya bisa dipendam.

f) Menyembunyikan Suatu Hal

Pelanggaran prinsip kerja sama yang terjadi dalam novel salah satunya memiliki maksud dan tujuan untuk menyembunyikan sesuatu hal dari orang lain. Hal tersebut dilakukan untuk menghindari kecurigaan dari orang-orang sekitar bahwa ia sedang memikirkan sesuatu, seperti dalam kutipan novel berikut:

Penutur: "Barangkali Lani ... tetapi Manen sudah ada rencana lain!" Philip yang duduk di sebelah Manen, menyenggolnya. "Betul, Manen?"

Kawan tutur: “Apa?” tanya Manen, tersentak dari lamunannya. Melihat wajah-wajah disekelilingnya terarah kepadanya penuh tanda tanya, ia cepat-cepat mengatakan, "Kan sudah 
kusanggupi ikut kongres nanti. Tak ada rencana lain."

Konteks pertuturan di atas terjadi ketika penutur menanyakan rencana yang akan dijalankan kawan tutur untuk seminggu ke depan. Dari pertuturan di atas, tampaknya jawaban yang diberikan oleh kawan tutur melebihi informasi yang dibutuhkan oleh penutur. Seharusnya, dengan kawan tutur cukup menjawab "tak ada rencana lain" sebab yang ditanyakan oleh penutur adalah "rencana apa yang akan dilakukan". Dengan kata lain, kawan tutur telah melakukan pelanggaran terhadap prinsip kerja sama, sebab memberikan informasi melebihi apa yang dibutuhkan. Pelanggaran tersebut sengaja dilakukan oleh kawan tutur sebab ia tidak ingin temannya curiga bahwa ada sesuatu hal yang ia sembunyikan.

\section{g) Mengungkapkan Suatu Hal}

Dalam pertuturan, seringkali kawan tutur memberikan jawaban yang tidak lugas untuk mengungkapkan suatu hal yang terjadi pada dirinya. Kawan tutur sengaja berbicara panjang lebar sebelum akhirnya ia sampai pada inti pembicaraan. Pengungkapan terhadap suatu hal secara panjang lebar dan tidak lugas menyebabkan terjadinya pelanggaran prinsip kerja sama dalam pertuturan. Seperti kutipan dalam novel berikut ini:

Penutur: "Wah Raumanen," senyum Monang, mencari tangannya. "Kau menjadi penyair?"

Kawan tutur: "Entahlah," kata Manen. "Tibatiba saja itu melintasi kalbuku. Barangkali aku sudah gila, deklamasi sajak tentang bulan yang sia-sia mencari orang ... sedangkan maksudku berbicara tentang orang yang sia-sia mengharapkan ... datang bulan ...." Suaranya putus.

Konteks pertuturan di atas membicarakan tentang kondisi kawan tutur yang hamil di luar nikah. Dari pertuturan tersebut, terlihat bahwa kawan tutur melanggar prinsip kerja sama, sebab ia memberikan jawaban yang tidak informatif dan berbelit-belit. Jawaban tersebut menyebabkan penutur bingung dengan maksud yang ingin diucapkan kawan tutur. Dalam hal ini, kawan tutur telah melanggar prinsip kerja sama. Pelanggaran itu terjadi karena kawan tutur ingin mengatakan kepada penutur bahwa dirinya hamil. Sebagaimana kita ketahui bahwa hamil di luar nikah merupakan suatu hal yang tergolong tabu dan merupakan perbuatan buruk, maka dari itu kawan tutur sengaja mengungkapkannya secara tidak lugas dan berbelit-belit sebab ia malu mengakuinya secar terangterangan.

h) Mencari-cari Alasan

Dalam novel Raumanen, peneliti menemukan bahwa maksud kawan tutur melakukan pelanggaran terhadap prinsip kerja sama adalah untuk mencari-cari alasan. Alasan ini sengaja digunakan untuk menghindari sesuatu yang tidak diinginkan, seperti terlihat dalam kutipan berikut:

Penutur: “Ada apa?” tanya Monang terkejut.

Kawan tutur: "Aku tak boleh punya anak!"

Penutur: “Apa maksudmu?" Monang melirik padanya, kurang sabar.

Kawan tutur: "Monag, aku hampir lupa sebetulnya tak pernah kuingat lagi .... Ketika aku berumur lima tahun, aku hampir menjadi buta."

Penutur: "Kau takut punya anak cacat?"

Kawan tutur: "Bukan ..." Manen menggelengkan kepala. "Ada hubungannya dengan kelainan pada syaraf mata. Aku tak tahu persoalannya .... Pokoknya, aku dilarang keras mengangkat barang-barang berat. Malahan aku pun tak boleh sampai semberlit. Dan dokter yang merawatku waktu kecil sering mengatakan aku takkan boleh melahirkan anak .... Bisa jadi buta!

Konteks pertuturan di atas membicarakan tentang pengalaman buruk yang pernah dialami oleh kawan tutur, yang menyebabkannya tidak boleh melahirkan anak. Dari pertuturan di atas, diketahui bahwa penutur ingin mengetahui alasan kawan tutur tidak boleh melahirkan anak. Namun, kawan tutur 
memberikan jawaban yang tidak bisa diyakini kebenarannya. Hal itu dapat dilihat dari kalimat "aku hampir lupa" dan "aku tak tahu persoalannya" yang menunjukkan keraguraguan. Kawan tutur juga tidak menyertai bukti-bukti yang memadai atas jawaban yang ia berikan, sehingga penutur sulit untuk memahami maksud dari kawan tutur. Dalam hal ini, kawan tutur telah melakukan pelanggaran terhadap prinsip kerja sama. Pelanggaran itu terjadi sebab kawan tutur ingin mencari-cari alasan agar ia tidak menikah dengan penutur. Ketidakinginan itu didasari oleh keraguan kawan tutur terhadap tanggung jawab dan kesetiaan pentur dalam membina rumah tangga.

Pembahasan di atas memperlihatkan bahwa pelanggaran-pelanggaran terhadap prinsip kerja sama yang dilakukan oleh para tokoh tidak lepas dari makud dan tujuan yang ingin dicapai. Dalam novel Raumanen karya Marianne Katoppo, pelanggaran terbanyak dilakukan dengan maksud untuk memberi penjelasan dan pemahaman yang lebih. Hal ini sekaligus menjadi ciri khas dalam karya sastra khususnya novel bahwa pesan-pesan yang ingin disampaikan oleh pengarang kepada pembaca terangkum dalam dialog-dialog para tokoh. Selain itu, ketidaklugasan bahasa dalam novel sebenarnya bertujuan untuk memberikan ruang bagi pembaca melakukan pengembaraan imajinasi dan penafsiran terhadap setiap peristiwa yang terjadi dalam novel.

\section{SIMPULAN}

Berdasarkan pada penjelasan di atas, ada beberapa hal yang bisa disimpulkan. Pertama, prinsip kerja sama merupakan objek kajian pragmatik yang menghendaki peserta tutur untuk memberikan kontribusi yang baik dalam pertuturan. Kedua, dalam novel Raumanen karya Marianne Katoppo, ditemukan adanya pematuhan dan pelanggaran terhadap prinsip kerja sama yang dicetuskan oleh Grice. Pematuhan prinsip kerja sama yang terjadi dalam dialog merupakan bentuk pemahaman terhadap konteks pertuturan, sehingga mereka dapat memberikan kontribusi yang baik pada saat komunikasi berlangsung. Selain itu, pelanggaran terhadap prinsip kerja sama merupakan hal yang paling banyak terjadi dalam novel. Pelanggaran ini terjadi bukan berarti para tokoh tidak memahami konteks pertuturan, tetapi ada maksud dan tujuan yang ingin mereka capai. Secara berurut, maksud dan tujuan itu adalah ingin memberi peringatan, meminta penjelasan, menciptakan humor, memberi penjelasan, sopan santun, menyem-bunyikan suatu hal, mengungkapkan suatu hal, dan mencari-cari alasan. Ketiga, pelanggaran terbanyak dilakukan dengan maksud untuk memberi penjelasan dan pemahaman yang lebih. Hal ini sekaligus menjadi ciri khas dalam karya sastra khususnya novel bahwa pesan-pesan yang ingin disampaikan oleh pengarang kepada pembaca terangkum dalam dialog-dialog para tokoh. Selain itu, ketidaklugasan bahasa dalam novel sebenarnya bertujuan untuk memberikan ruang bagi pembaca melakukan pengembaraan imajinasi dan penafsiran terhadap setiap peristiwa yang terjadi dalam novel.

\section{DAFTAR PUSTAKA}

BAM, S. A., Setiawan, B., \& Saddhono, K. (2018). "Penggunaan Bahasa Indonesia Pada Diskusi Siswa Smanegeri 4 Surakarta: Kajian Dengan Prinsip Kerja Sama Grice Dan Relevansinya Sebagai Bahan Ajar Keterampilan Berbicara." Basastra: Jurnal Bahasa, Sastra, dan Pengajarannya, 6, 281-301.

Beden, S., \& Zahid, I. (2015). "Analisis Kesopanan Bahasa dalam Novel Melunas Rindu: Aplikasi Maksim Leech dan Grice." Jurnal Bahasa, 15. 143-172.

Fauziah, M. T., Emzir, E., \& Lustyantie, N. (2018). "Pelanggaran Prinsip Kerja Sama dalam 
Tuturan Diskusi Kelas Bahasa Indonesia. JP-BSI". Jurnal Pendidikan Bahasa dan Sastra Indonesia, 3. 51-57.

Kushartanti. 2009. Pesona Bahasa. Jakarta: Gramedia, cet. 3.

Leech, G. 1993. Prinsip-prinsip Pragmatik. Jakarta: UI Press.

Lestari, N. W. P., Sudiana, I. N., \& Artika, I. W. (2019). "Prinsip Kerja Sama Dalam Novel Magening Karya Wayan Jengki Sunarta." Jurnal Imiah Pendidikan dan Pembelajaran, 3(3), 384-393.

Lyra, H. M., Gunardi, G., \& Muhtadin, T. 2020. "Analisis Kepatuhan Terhadap Prinsip Kerja Sama Grice Dalam Komik Sunda Si Mamih An Analysis Of Grice's Cooperative Principle In Sundanese's Comic 'Si Mamih'..' Jurnal Kata: Penelitian Tentang Ilmu Bahasa dan Sastra, 4(1), 11-19.

Maemunah, S. (2019). Implikatur Percakapan dalam Novel Pesantren Impian Karya Asma Nadia. El Banar: Jurnal Pendidikan Dan Pengajaran, 2(01), 44-48.

Panduwinata, A. (n.d.). Penciptaan Humor Dalam Film-Film Benyamin Sueb Berbahasa Betawi Melalui Pelanggaran Maksim-Maksim.

Rahardi, R. K. 2005. Pragmatik: Kesantunan Imperatif Bahasa Indonesia. Erlangga.

Savitri, R., Fuad, M., \& Rusminto, N. E. (2015). "Pelanggaran prinsip kerjasama dalam novel Rantau 1 Muara karya Ahmad Fuadi." J-SIMBOL (Bahasa, Sastra, dan Pembelajarannya), 3(1).

Shinta, Q. 2010. "Pemerolehan Pragmatik Dalam Bahasa Anak Studi Kasus Prinsip Kerja Sama-Maksim Grice Pada Anak Usia Enam (6) Tahun." Dinamika Bahasa dan Budaya, 4(2), 66-83.

Tiara, A. T. 2017. Pelanggaran Prinsip Kerjasama dalam Anime Gintama Episode 3-Episode 5. Universitas Andalas.

Veronika, R., Sinaga, M., \& Rumadi, H. (2017). Pelanggaran Prinsip Kerjasama dalam Novel 5 Cm Karya Donny Dhirgantoro. Riau University.

Yuliana, R., Rohmadi, M., \& Suhita, R. (2013). "Daya Pragmatik Tindak Tutur Guru Dalam Pembelajaran Bahasa Indonesia Pada Siswa Sekolah Menengah Pertama". BASASTRA, 2(1).

Yuniseffendri, S. 2011. Pragmatik. Jakarta: Universitas Terbuka. Cet. 3. 